Jacek Skrzydło

\title{
Immunitet państwa a immunitet przedstawiciela państwa w orzecznictwie Sądu Najwyższego Stanów Zjednoczonych
}

Stany Zjednoczone należą do tych państw, które zdecydowały się wprowadzić do prawa krajowego regulacje dotyczące wykonywania jurysdykcji w stosunku do państw obcych. Obowiązująca w USA od 1976 r. ustawa o immunitetach państw obcych (FSIA ${ }^{1}$ ) przewiduje jako zasadę immunitet jurysdykcyjny pozwanego obcego państwa w postępowaniu cywilnym. Orzecznictwo na tle FSIA jest bogate, poszczególne postanowienia były wielokrotnie przedmiotem gruntownej analizy przez sądy federalne; dotyczy to także pojęcia ,państwo” dla celów ustawy. FSIA nie reguluje jednak wprost, czy przez ,państwo” należy dla celów immunitetu jurysdykcyjnego rozumieć także funkcjonariuszy państwa działających w urzędowym charakterze.

Przedstawienie rozwiązań amerykańskich należy poprzedzić opisem kontekstu międzynarodowego. Analiza rozwiązań przyjmowanych w porządkach krajowych oraz w umowach międzynarodowych regulujących problematykę immunitetów upoważnia bowiem do postawienia wniosku do daleko idącej konwergencji immunitetu państwa oraz immunitetu głowy państwa, z zastrzeżeniem istotnych różnic i funkcji spełnianych przez te instytucje. Charakterystyczne jest jednak, że bardzo często immunitet państwa obejmuje lub przynajmniej dotyczy z reguły także samej głowy państwa, a także innych przedstawicieli państwa.

Jeżeli chodzi o rozwiązania brytyjskie, to zgodnie z sekcją 14.1 a) State Immunity Act (SIA)², ochroną przewidzianą dla ,państwa” objęty jest także

${ }^{1} \mathrm{http}: / /$ www.law.cornell.edu/uscode/html/uscode28

${ }^{2}$ www.statutelaw.gov.uk 
„suweren lub inna głowa państwa działająca w wykonaniu funkcji publicznej”3. Uzupełniająco sekcja 20 SIA zrównuje co do zakresu przysługującej ochrony status głowy państwa ze statusem szefa misji dyplomatycznej, co zresztą może być powodem komplikacji i budzić zastrzeżenia: dyplomata przebywa na terytorium państwa przyjmującego, w „zasięgu” jego jurysdykcji terytorialnej; natomiast głowa państwa, $\mathrm{z}$ wyjątkiem wizyt oficjalnych, wykonuje swoje funkcje u siebie w państwie ${ }^{4}$. Ponieważ jednak immunitet państwa siłą rzeczy nie może dotyczyć kwestii związanych z odpowiedzialnością karną, odesłanie do regulacji mających zastosowanie w przypadku osób chronionych immunitetem dyplomatycznym zapewnia głowie państwa niezbędną ochronę także i w tym zakresie.

Praktyka brytyjska odzwierciedla tendencję, która daje się zauważyć w prawie międzynarodowym i która sprowadza się do zbliżenia - dla celów immunitetu jurysdykcyjnego - pozycji głowy państwa z pozycją samego państwa ${ }^{5}$. Dowodem na to jest projekt Konwencji ONZ o immunitetach jurysdykcyjnych państwa i własności państwowej: termin „państwo" dla celów Konwencji oznacza cztery różne kategorie podmiotów. $Z$ punktu widzenia niniejszego opracowania istotna jest kategoria pierwsza, obejmująca samo państwo i organy władzy publicznej, oraz kategoria czwarta, obejmująca osoby fizyczne reprezentujące państwo w sprawach, których dotyczą trzy pierwsze kategorie. Oznacza to, że ostatnia grupa desygnatów szeroko rozumianego „państwa” obejmuje wszystkie osoby uprawnione do reprezentowania państwa i pokrywa się częściowo z trzema pierwszymi. W konsekwencji głowa państwa lub suweren działający w wykonywaniu władzy publicznej mieszczą się zarówno w pierwszej, jak i w czwartej kategorii, będąc organami państwa w szerokim tego słowa znaczeniu. Z komentarza do projektu Konwencji autorstwa Komisji Prawa Międzynarodowego wynika, że był to zabieg celowy: termin „,państwo" powinien być rozumiany jako obejmujący wszystkie typy i kategorie bytów i jednostek, które mogą korzystać z ochrony wynikającej z immunitetu państwa (komentarz do art. 2) ${ }^{6}$. W każdym razie treść projektu Konwencji wyraźnie wskazuje, że chroni ona głowę państwa immunitetem ratione materiae, tj. immunitet ten obejmuje wyłącznie działania głowy państwa w wykonywaniu władzy publicznej. Immunitet ten po pierwsze ma charakter cywilny (bo państwa nie ponoszą odpowiedzialności karnej, stąd nie jest możliwe, aby Konwencja dotyczyła sfery odpowiedzialności karnej głowy państwa), po drugie - obowiązuje tak podczas wykonywania funkcji głowy państwa, jak i po odejściu z urzędu.

${ }^{3}$ Podobne brzmienie ma sekcja 3(3)(b) australijskiej ustawy z 1985 r. o immunitetach państw obcych: „reference in this Act to a foreign State includes a reference to the head of a foreign State, or of a political subdivision of a foreign State, in his or her public capacity"; cyt. za: http://www. comlaw.gov.au/ComLaw/Legislation

${ }^{4}$ H. Fox, The Law Of State Immunity, Oxford 2002, s. 446.

5 Ibidem, s. 437-438.

${ }^{6}$ Draft Articles on Jurisdictional Immunities of States and their Property, with commentaries, http://untreaty.un.org/ilc/texts/instruments/.../commentaries/4_1_1991.pdf 
Ponieważ zwyczajowe prawo międzynarodowe chroni głowę państwa immunitetem $\mathrm{w}$ szerszym zakresie ( $\mathrm{w}$ tym przed odpowiedzialnością karną przed obcym sądem), autorzy projektu Konwencji wprowadzili do jej art. 3 par. 2 normę kolizyjną, która przewiduje, że postanowienia Konwencji nie naruszają przywilejów i immunitetów ratione personae przysługujących głowie państwa na podstawie prawa międzynarodowego. Immunitet ratione personae ma z jednej strony szerszy zakres niż immunitet ratione materiae, gdyż chroni wszelkie działania głowy państwa, tj. zarówno o charakterze publicznym, jak i niepublicznym; z drugiej strony przysługuje głowie państwa tylko w czasie sprawowania funkcji.

W przeciwieństwie do Konwencji ONZ uchwalona znacznie wcześniej pod auspicjami Rady Europy konwencja z Bazylei o immunitecie państwa ${ }^{7}$ nie precyzuje, w jaki sposób należy rozumieć termin „państwo”, gdyż posługuje się w art. 27 definicją negatywną, tj. wyłącza spod pojęcia „państwo” jednostki organizacyjne państwa odrębne od tego państwa i zdolne do pozywania lub bycia pozwanymi, nawet jeśli jednostki te ustawodawca krajowy wyposażył w funkcje publiczne. Konwencja ta w żaden sposób nie odnosi się natomiast do problemu immunitetu przysługującego głowom państwa.

Ustawa amerykańska różni się od rozwiązań brytyjskich, australijskich lub przyjętych w Konwencji ONZ z 2004 r. Zawarta w jej § 1603 definicja „państwa" dla celów stosowania ustawy jest węższa i obejmuje:

a) część składową obcego państwa (political subdivision) lub;

b) inną jednostkę organizacyjną (agency or instrumentality), przy czym ,jednostka organizacyjna" oznacza każdy byt (entity) posiadający osobowość prawną i jednocześnie będący organem obcego państwa lub jego części składowej, lub w którym państwo obce lub jego część składowa posiada więcej niż połowę udziałów.

W tak zakreślonych ramach prawnych można przystąpić do opisu stanu faktycznego sprawy Samantar v. Yousuf, zakończonej wyrokiem Sądu Najwyższego USA z 1 czerwca $2010 \mathrm{r}^{8}$

Powodowie, obywatele Somalii mieszkający z USA, pozwali do sądu federalnego Mohammeda Ali Samantar (także zamieszkałego w USA; w latach 80-tych pełniącego obowiązki szefa rządu Somalii ${ }^{9}$ ) na podstawie ustawy o ochronie ofiar tortur (Torture Victim Protection Act; TVPA) oraz na podstawie ustawy o deliktach popełnionych przez cudzoziemców (Alien Tort Statute; ATS), zarzucając pozwanemu popełnienie na terenie Somalii czynów kwalifikowanych jako tortury oraz inne ciężkie naruszenia podstawowych praw człowieka. Po różnych rozstrzygnięciach w niższych instancjach (federalny sąd pierwszej instancji przyznał pozwanemu immunitet na podstawie FSIA; Sąd Apelacyjny IV Okręgu orzekł odmiennie), Sąd Najwyższy stanął w obliczu następujących kwestii prawnych:

${ }^{7}$ Tekst za: http://conventions.coe.int/treaty/en/Treaties/Html/074.htm

8560 US (2010); cyt. za: www.oyez.org

9 Pozwany został opisany jako ,petitioner, who then held high level government positions, exercised command and control over the military forces committing the abuses". 
czy wynikający z FSIA immunitet jurysdykcyjny państwa obcego obejmuje także funkcjonariuszy tego państwa działających w imieniu obcego państwa, a jeżeli tak, to jakie są zasady korzystania z tego immunitetu przez osobę, która już nie zajmuje stanowiska we władzach obcego państwa.

Opierając się przede wszystkim na gramatycznej wykładni FSIA, Sąd Najwyższy doszedł do wniosku, że FSIA reguluje wyłącznie immunitet państwa i jego jednostek organizacyjnych; nie dotyczy natomiast immunitetów o charakterze personalnym. Z treści FSIA nie wynika bowiem, aby pojęcie „państwo obce” miało być rozumiane jako obejmujące także funkcjonariusza państwa działającego $\mathrm{w}$ takim charakterze. Zawarte $\mathrm{w}$ ustawie wskazówki, jak rozumieć pojęcie agency or instrumentality, wykluczają przyjęcie, że chodzić to może o osoby fizyczne, gdyż użyte w tekście słowo entity zazwyczaj odnosi się do organizacji mających podmiotowość prawną. Poza tym w samej ustawie znajdują się w innych jej częściach wyraźne nawiązania do urzędników działających w takim charakterze, jeżeli ich działanie ma być przypisywalne państwu.

Także historia procesu legislacyjnego oraz cele, jakimi kierował się Kongres, uchwalając FSIA, sprzeciwiają się przyjęciu, że FSIA obejmuje przedstawicieli państwa: chodziło o kodyfikację reguł immunitetu państwa i nic nie wskazuje na to, że Kongres - z pewnością znając różnicę między immunitetem państwa a immunitetem jego przedstawiciela - dokonał w dorozumiany sposób kodyfikacji obowiązującego common law także i w tej drugiej kwestii. W konsekwencji Sąd Najwyższy przyjął, że FSIA nie ma zastosowania do immunitetu przedstawiciela państwa; ta dziedzina regulowana jest w dalszym ciągu przez prawo zwyczajowe i na podstawie jego reguł sądy powinny w toku dalszego postępowania zbadać podstawy jurysdykcji w sprawie. Innymi słowy, Sąd Najwyższy, oczyszczając przedpole, wyeliminował z kontekstu normatywnego sprawy postanowienia FSIA, nakazując skoncentrowanie się na prawie zwyczajowym.

Praktyka sądów amerykańskich w przedmiocie immunitetu przedstawiciela państwa obcego nie jest szczególnie bogata, a wydawane rozstrzygnięcia nie zawsze wyczerpują problem. W pierwszej kolejności wskazać trzeba na wydany jeszcze w XIX w. wyrok w sprawie Underhill v. Hernandez ${ }^{10}$. Sprawa dotyczyła amerykańskiego obywatela, który w czasie wojny domowej w Wenezueli został zmuszony przez siły rewolucyjne (które następnie objęły władzę w kraju, a nowy rząd został uznany przez USA) do wykonania określonych robót wodnych w Ciudad Bolivar; odmówiono mu wydania zezwolenia na opuszczenie kraju aż do czasu ukończenia tych robót. Pozwanym był ówczesny dowódca sił rewolucyjnych w Wenezueli. Sąd Najwyższy uznał, że pozwany chroniony jest immunitetem, a sądy amerykańskie nie powinny orzekać o legalności działań obcych rządów. Immunitet funkcjonariuszy państwa obcego za działania przedsięwzięte w wykonaniu władzy państwowej dotyczy zarówno urzędników cywilnych, jak i wojskowych, także wykonujących swoje funkcje de facto.

10168 U.S. 250 (1897). 
Problem immunitetu głowy państwa pojawił się także w postępowaniu karnym. W sprawie US v. Noriega ${ }^{11}$ Sąd Apelacyjny 11 Okręgu, rozpoznając apelację oskarżonego m.in. o przemyt narkotyków do USA, nie uznał podniesionego przez niego zarzutu immunitetu głowy państwa z uwagi na fakt, że rządzący de facto w Panamie generał Noriega (de iure szef wywiadu i sił zbrojnych Panamy) nigdy nie był przez USA uznany za głowę państwa.

W 2004 r. sądy amerykańskie zajmowały się immunitetem głowy państwa w sprawach cywilnych o odszkodowanie za naruszenie praw człowieka. Sprawy dotyczyły urzędującego prezydenta Zimbabwe (Robert Mugabe) i Prezydenta Chin (Jiang Zemin), który w czasie orzekania nie pełnił już tej funkcji ${ }^{12}$. W sprawie dotyczącej Roberta Mugabe ${ }^{13}$, federalny sąd okręgowy przyjął sugestię Departamentu Stanu, zgodnie z którą urzędująca głowa państwa korzysta mocą prawa międzynarodowego $\mathrm{z}$ absolutnego immunitetu ${ }^{14}$; dodatkowo pozwany w czasie doręczenia mu pozwu był uprawniony do immunitetu dyplomatycznego na podstawie konwencji o przywilejach i immunitetach Narodów Zjednoczonych. Sąd Apelacyjny, utrzymując w mocy to rozstrzygnięcie, ograniczył się jednak wyłącznie do podstaw immunitetu wynikających z Konwencji ONZ, nie wypowiadając się o immunitecie głowy państwa.

W sprawie dotyczącej Jiang Zemina powodami byli członkowie zakazanej w Chinach sekty Falun Gong, którzy żądali odszkodowania za tortury i inne naruszenia podstawowych praw człowieka, do jakich doszło w Chinach w stosunku do członków sekty. Podobnie jak w sprawie Mugabe, także i w tym przypadku Departament Stanu USA złożył w sądzie pismo sugerujące uznanie immunitetu głowy państwa, mimo że w czasie orzekania Jiang Zemin nie pełnił już tej funkcji. Federalny sąd okręgowy, podobnie jak w przypadku pozwu dotyczącego byłego prezydenta Nigerii ${ }^{15}$, uznał, że Zemin pomimo odejścia $\mathrm{z}$ urzędu w dalszym ciągu korzysta z pełnego immunitetu (ratione personae), nawet jeżeli zarzucane działania stanowiły pogwałcenie norm ius cogens. Sąd Apelacyjny utrzymał w mocy to rozstrzygnięcie, uznając, że pismo Departamentu Stanu z sugestią immunitetu było wiążące dla sądu; w tym stanie rzeczy zbędne było rozważanie zakresu immunitetu przysługującego byłej głowie państwa oraz analiza wpływu ewentualnego naruszenia przez pozwanego norm ius cogens na zakres tego immunitetu.

${ }^{11}$ United States v. Noriega, 746 F. Supp. 1506, 1525 (S.D.Fla.1990); podobnie Kadic v. Karadzic, 74 F.3d 377 (2nd Cir.(N.Y.)).

${ }^{12}$ S. Andrews, US. Courts Rule on Absolute Immunity and Inviolability of Foreign Heads of State: The Cases against Robert Mugabe and Jiang Zemin, http://www.asil.org/insight041122.cfm

13 Tachiona v. United States, 386 F.3d 205.

14 Jeżeli sprawa wszczęta przed sądem amerykańskim dotyczy urzędującej głowy państwa, Departament Stanu składa do sądu pismo „sugestię immunitetu”, stosownie do 28 U.S.C. par. 517. Sugestia ta jest uważana za ostateczną i wiąże sąd orzekający.

${ }^{15}$ Abiola v. Abukar, 267 F. Supp. 2d 907, 915-17 (N.D. Ill). 
Z powyższego wynika, że w przeciwieństwie do zasad wykonywania jurysdykcji w stosunku do obcych państw, praktyka amerykańska dotycząca immunitetu głowy państwa nie daje zbyt wiele wskazówek co do zakresu i charakteru tego immunitetu. Korzystanie przez sądy z sugestii Departamentu Stanu przypomina nieco praktykę ukształtowaną po 1952 r., kiedy to Stany Zjednoczone zgodnie z tzw. Tate Letter przyjęly restryktywną teorię immunitetu państwa, a sądy federalne poszukiwały wskazówek u władzy wykonawczej, nie chcąc wkraczać w drażliwą niekiedy problematykę stosunków międzynarodowych. 